International Research Journal of Management, IT \& Social Sciences
Available online at https://sloap.org/journals/index.php/irjmis/
Vol. 6 No. 3, May 2019, pages: $61 \sim 69$
ISSN: 2395-7492
https://doi.org/10.21744/irjmis.v6n3.630

\title{
The Effect of Role Conflict, Role Ambiguity, and Role Overload in Burnout Government Internal Supervisors with Tri Hita Karana Culture as Moderation
}

\author{
Ida Yuni Pratiwi ${ }^{\text {a }}$ \\ Ni Made Dwi Ratnadi ${ }^{b}$ \\ Herkulanus Bambang Suprasto ${ }^{c}$ \\ I Ketut Sujana ${ }^{d}$
}

\section{Article history:}

Received: 27 December 2018

Accepted: 31 March 2019

Published: 3 May 2019

\section{Keywords:}

burnout;

role ambiguity;

role conflict;

role overload;

THK;

\begin{abstract}
This study aims to obtain empirical evidence of Tri Hita Karana's cultural abilities in moderating the effect of role conflict, role ambiguity, and the role overload in burnout experienced by the Government Internal Supervisory Apparatus (APIP) at the Inspectorate of Bali Province. The technique of determining the sample used is saturated sampling (census). The number of respondents was 47 APIP. The data used is in the form of primary data. Data collection using survey methods using questionnaires. The analysis technique used in this study is Partial Least Square (PLS). The results of the analysis show that the culture of Tri Hita Karana causes the effect of role conflict and the role of overload in reduced burnout. However, Tri Hita Karana's culture does not moderate the effect of the role ambiguity on burnout experienced by the APIP at the Inspectorate of Bali Province.
\end{abstract}

2395-7492@ Copyright 2019. The Author. This is an open-access article under the CC BY-SA license (https://creativecommons.org/licenses/by-sa/4.0/) All rights reserved.

\section{Author correspondence:}

Ida Yuni Pratiwi,

Faculty of Economic and Business Udayana University, Bali, Indonesia.

Email address: idayupy8@gmail.com

\section{Introduction}

APIP was formed to oversee the administration of the government, especially the financial management sector to run according to the provisions and laws and regulations. In carrying out its duties, APIP acts independently and has responsibilities to interested parties on audited financial statements. APIP will make decisions based on the evidence and facts obtained in the field.

\footnotetext{
${ }^{\text {a }}$ Faculty of Economic and Business Udayana University, Bali, Indonesia

${ }^{\mathrm{b}}$ Faculty of Economic and Business Udayana University, Bali, Indonesia

${ }^{\mathrm{c}}$ Faculty of Economic and Business Udayana University, Bali, Indonesia

${ }^{\mathrm{d}}$ Faculty of Economic and Business Udayana University, Bali, Indonesia
} 
In its efforts to find audit evidence, APIP conducts boundary spanning activities, namely APIP must interact with many people, both from inside and outside the organization who have different needs and expectations to obtain information that is useful in decision making. Individuals who are in a boundary-spanning situation have the potential to experience pressure due to their role. APIP is a profession that has the potential to experience depression because of the many pressures in its work. The stress experienced by APIP can also occur considering that APIP's duties and responsibilities are very heavy, the scope of supervision is extensive, the level of complexity of the work is high (Wiryathi et al., 2014).

Stress can have a positive or negative impact. Hans Selye (1956) in Wikaningtyas (2007), states that there are two types of stress namely eustress, namely stress that has a positive impact on human life and distress that has a negative impact. Stress at a certain level can actually motivate someone to improve performance and complete their work. Some people are said to be able to positively utilize stress to capture opportunities and perform with or close to their maximum level of ability. Many professionals see the pressure in the form of a heavy workload and short deadlines as a positive challenge to be able to increase the quality of work and satisfaction gained from their work (Robbins and Judge, 2008). But excessive levels of stress can have a negative impact that tends to reduce performance, job satisfaction, and can lead to psychopathological symptoms such as depression and anxiety (Wikaningtyas, 2007). The type of stress that has a negative or dysfunctional (distress) impact on performance is called burnout (Kalbers \& Fogarty, 2005; Utami \& Nahartyo, 2013).

Burnout is the term first expressed by Freudenberger (1974), which is a representation of psychological stress syndrome, which shows a negative response as a result of work pressures (Cordes and Dougherty, 1993; Murtiasri and Ghozali, 2006). Maslach \& Jackson (1981), define burnout as a psychological syndrome of emotional and personalized fatigue, which arises among individuals who work with others. Someone who experiences this condition will lose energy, enthusiasm for life, and self-confidence. According to Maslach \& Leiter (1997), burnout generally arises due to disharmony between work with individuals who do these jobs and work pressures. These work pressures can lead to emotional and physical fatigue (burnout), which in turn can reduce auditor performance.

Bakar \& Salleh (2015), reveal that the role played by a person can be a factor causing stress because someone in his life does not only play one role. Role theory suggests that employees will increasingly be unable to handle each role successfully if they take many roles in a row, which in turn will cause conflict. Fogarty et al., (2000), noted that symptoms of burnout occur in the profession of public accounting or auditors, internal auditors, and management accountants.

Research on stress and burnout in the auditor profession is increasingly being done because excessive stress can have a negative impact on performance and health. Excessive stress experienced by auditors can also have a negative impact on agencies such as increased absenteeism, low productivity, high employee turnover rates, and job dissatisfaction (Wiryathi et al., 2014). The cause of burnout that will be discussed in this study is the role pressure which consists of role conflict, role ambiguity, and role overload.

Kalbers \& Fogarty (2005), state that academic research focuses on role conflict, role ambiguity and role overload as causes of burnout. In addition, according to Cordes \& Dougherty (1993), the antecedents of burnout are role conflict, role ambiguity, and role overload. Fogarty et al., (2000) and Murtiasri \& Ghozali (2006), found a positive effect on role conflict, role ambiguity, and role overload in burnout.

Role conflict refers to the incompatibility of expectations and demands related to roles (Idris, 2011). Role conflict arises when an individual is expected to act in ways that conflict with his needs, capacities, and values (Viator, 2001). Role conflict creates expectations that may be difficult to resolve or fulfill (Robbins \& Judge, 2008). Role conflict is a conflict or confusion that occurs because of the simultaneous occurrence of two or more forms of pressure on the workplace, where the fulfillment of one role makes fulfilling other roles more difficult. Utami \& Nahartyo (2013), state that within the accounting profession, role conflict arises from two consecutive but inconsistent orders. This results in the auditor having to work extra, involving emotions and not a little effort to do his job (Fogarty, et al 2000). If such conditions continue, the auditor can experience burnout (Maslach, 1982 in Fogarty et al., 2000).

Role ambiguity arise when individuals do not have clear authority or knowledge about how to do the assigned work (Idris, 2011). The lack of clarity occurs when role expectations are not clearly understood and employees are not sure what to do (Robbins \& Judge, 2008). Auditors often only have a small amount of information that is sufficient to do their work or what is their responsibility in their current role (Jones et al., 2010). This lack of information or unclear direction and direction causes mental fatigue, because under conditions of ambiguity the individual needs high energy and mentality, leading to burnout (Maslach \& Jackson, 1984).

Excess roles occur when expectations for roles are greater than the abilities and motivations of individuals to perform tasks (Idris, 2011). The number of tasks given in a limited period of time or the work gave is too difficult and 
exceeds the ability, can cause a person to become tired, both physically and mentally. Yustrianthe (2008), states that professionals who experience prolonged role excess can experience a tendency to evaluate themselves negatively with respect to their accomplishments. This causes burnout and as a result, this can lead to dissatisfaction, and the desire to burnout.

Research on the relationship between role conflict, role ambiguity and the overload of roles with burnout has resulted in inconsistent findings. Murtiasri \& Ghozali (2006) and Budiasih (2017), found a positive effect on role conflict, role ambiguity, and role overload in burnout experienced by auditors, but Budiadnyani (2017), found a negative effect on role conflict and role ambiguity in burnout. Jawahar et al., (2007) and Ghorpade et al., (2011) found role conflict had a positive effect on burnout, but Lina \& Kusuma (2018) found role conflict had a negative effect on burnout. Fogarty et al., (2000), found role conflict, role ambiguity, and role overload a positive effect on burnout, but Jones, et al (2010) found no evidence of the effect of role conflict on burnout, and Utami \& Nahartyo (2013), found no evidence of the effect of role ambiguity on burnout, caused by the presence of other variables that affect the effect of role conflict, role ambiguity, and role overload in burnout. The variables in question are mediating variables and moderating variables. The moderating variable used in this study is the culture of Tri Hita Karana.

Culture has to do with the stress experienced by individuals. Keinan \& Perlberg (1987) in Glazer \& Beehr (2005), argue that one's culture tends to affect the intensity of stress that affects individuals. Culture can be used as an independent variable or a moderating variable in the meta-analysis conducted by Dewi et al., (2018), there are 55 studies that make culture as an independent variable and 38 studies that make culture a moderating variable. The use of THK culture as a moderating variable among others has been carried out by Adiputra (2014), which states that THK culture moderates the effect of task complexity on internal auditor performance at the Bali Provincial Inspectorate Office, while Mustikayani \& Dwirandra (2016), get results that THK culture does not moderate the effect of complex assignments to auditor performance. Budiadnyani (2017), found that the Tri Hita Karana culture weakened the effect of role conflict and role overload on auditor performance.

BudayaTri Hita Karana (THK) is someone's behavior actualization, where THK culture is able to form good individual characters. Tri Hita Karana (THK) is the three causes of welfare or happiness (Suryani et al., 2009). The concept of THK is the concept of harmonizing relationships that are always guarded by the Balinese Hindu community including parahyangan (human relations with God), pawongan (human relations), and palemahan (human and environmental relations) (Riana, 2010). THK has become a life philosophy holistic and unique because it only exists in Bali and is rooted in Hinduism (Ariyanto, 2014). THK emphasizes the balance theory which states that Hindu societies tend to view themselves and their environment as a system controlled by balance and manifested in a form of behavior (Gunawan, 2009).

THK is a process of acculturation of local culture with organizational culture. This is reinforced by the vision of development in Bali Province in 2006-2026, namely "Bali Dwipa Rich, Fair, and Democratic, and Safe and Unified, in the Context of the Unitary State of the Republic of Indonesia Based on Tri Hita Karana" (Windia \& Dewi, 2007) and also there is a program of the Regional Government of Bali that organizes Tri Hita Karana Award for government agencies, schools, hotels and other educational institutions in Bali. Therefore, THK must be implemented in every development area in Bali, including being applied in government agencies in Bali, especially at the Provincial Inspectorate. Bali.

\section{Literature Review}

\section{The Ability of Tri Hita Karana Culture Moderating on the Effects of Role Conflict on Burnout}

The culture of Tri Hita Karana emphasizes the balance theory which states that Hindu societies tend to view themselves and their environment as a system that is controlled by the value of balance, and manifested in the form of behavior (Gunawan, 2009). If the THK concept is associated with an organization, in the dimensions of parahyangan a member of the organization has confidence that the success achieved is not solely because of their ability and hard work but rather because of God's will. A harmonious relationship with God can be built by believing and devoting to God (Wiana, 2007). Belief and devotion to God can increase one's ability to control themselves against various negative actions that can harm others. The self-approach to God is felt as a religious force that causes one to think calmly and clearly (Putra, 2000). The understanding of the culture of Tri Hita Karana can make APIP more rigid, calmer and think clearly so that it can make wiser decisions in overcoming role conflicts. Then the hypothesis proposed is:

H1: Tri Hita Karanas culture weakens the effect of role conflict on burnout

Pratiwi, I. Y., Ratnadi, N. M. D., Suprasto, H. B., \& Sujana, I. K. (2019). The effect of role conflict, role ambiguity, and role overload in burnout government internal supervisors with tri hita karana culture as moderation. International Research Journal of Management, IT and Social Sciences, 6(3), 61-69. 


\section{The Ability of Tri Hita Karana Culture Moderating on the Effects of Role Ambiguity on Burnout}

Tri Hita Karana's culture, the dimension of pawongan is related to harmonious relations between human beings which is manifested through the cultivation of teachings of manners or morality (Hindu ethics). This teaching provides guidance on how we respect each other and respect each other. Pitana (2002b), explains in relation to the dimension of pawongan someone has the view that humans do not live alone in this world and that humans always expect help from each other. Likewise, Wiana (2007), explained that a harmonious relationship between humans and humans can be realized by building unity to equalize perceptions, missions, and visions which are a concept of togetherness and devotion to God. The dimension of Pawongan is relevant to the organizational culture dimension Stein (2004), about making a clear system of reward and punishment, determining vision and mission, clarity in the distribution of power and status and developing goals in the form of organizational structure and division of tasks. APIP's understanding of Tri Hita Karana culture will also increase the persistence of APIP in work and the ability to establish harmonious relationships with colleagues so that APIP can position itself well in overcoming the ambiguity of the role. So the hypothesis proposed is:

H2: Tri Hita Karanas culture weakens the effect of role ambiguity on burnout

\section{The Ability of Tri Hita Karana Moderates the Strengths of Role Overload on Burnout}

The culture of Tri Hita Karana, the dimensions of parahyangan is related to the harmonious relationship between humans and God built by believing and devoting to God (Wiana, 2007). Someone who understands the culture of Tri Hita Karana views that work done as a service and worship, as well as success is not only from human endeavors but there are other powers that make the work easy to do (Ariyanto, 2014). Understanding of Tri Hita Karanam's culture is able to encourage APIP to work sincerely, selfless hard work so that it can be calmer and accept with sincerity the existence of excess roles. So the proposed hypothesis is

H3: Tri Hita Karana's culture weakens the effect of the role overload on burnout

\section{Materials and Methods}

The research location is the Inspectorate of Bali Province. The population in this study are all the Inspectorate Offices of Bali Province who participated in the inspection assignments in 2018, namely as many as 47 people consisting of 4 Regional Assistant Inspectors, functional Local Government Affairs Inspector Officials (P2UPD) 11 people and functional auditors 32 people. Data collection methods used in this study are survey methods using questionnaires. The hypothesis was tested with a 5 percent significance level using Partial Least Square (PLS) using the SmartPLS 3.0 application. This study tested the hypothesis with PLS because this study has a weak theoretical basis, especially with regard to the culture of Tri Hita Karana which had not previously been associated with role conflict, role ambiguity, role overload, and burnout.

\section{Results and Discussions}

Table 1

Hypothesis

\begin{tabular}{lll}
\hline Information & $\begin{array}{l}\text { Original } \\
\text { Sample } \\
\text { Estimate Value }\end{array}$ & Significance \\
\hline Role Conflict *THK -> Burnout & $-0,118$ & 0,040 \\
Unclear Role *THK -> Burnout & 0,009 & 0,942 \\
Role over *THK -> Burnout & $-0,231$ & 0,031 \\
\hline
\end{tabular}

Primary Data, 2018

The hypothesis (H1) states that the culture of Tri Hita Karana weakens the effect of role conflict on burnout. Table 1 shows that the Tri Hita Karana culture weakens the effect of role conflict on burnout is significant with a p-value of 
0.040 smaller than 0.05 . The original sample estimate value is negative, which is equal to $-0,181$ which indicates that Tri Hita Karanam's culture weakens the influence of role conflict on the outline. Thus the first hypothesis (H1) in this study which states that the culture of Tri Hita Karana weakens the influence of role conflict on the whole received.

The relationship of the Tri Hita Karan cultural variable with the dependent variable can be seen from the significance value with a p-value of 0,000 , less than 0.05 . The interaction of Tri Hita Karan's cultural variables with independent variables can be seen from the significance value of interaction of role conflict variables with the cultural variable Tri Hita Karana with p-value of 0.040, smaller than 0.05. By considering the direct influence of independent variables with independent variables, and the interaction between independent variables and moderating variables, the cultural variable Tri Hita Karana is classified into the type of quasi moderator. Quasi moderators are moderating variables that are related to dependent and/or independent variables and interact with independent variables (Ghozali, 2013).

Hypothesis (H2) states that the Tri Hita Karana culture weakens the influence of role ambiguity on burnout. Table 5.7 shows that the culture of Tri Hita Karanam weakens the influence of the role ambiguity on burnout is not significant because the p-value is 0.942 , greater than 0.05 . The original sample estimate value is positive which is equal to 0.009 which indicates that the Tri Hita Karana Culture does not moderate the role ambiguity in burnout. Thus the H2 hypothesis in this study which states that the Tri Hita Karanam culture weakens the influence of the ambiguity of roles in the rejected burnout.

The relationship of the cultural variable Tri Hita Karana with the dependent variable can be seen from the significance value with a p-value of 0,000 , less than 0.05 . The interaction of the cultural variable Tri Hita Karana with the independent variable can be seen from the significance value of the interaction of the role ambiguity variable with the Tri Hita Karana cultural variable, namely with a p-value of 0.942 , greater than 0.05 . This shows that the interaction of obscurity variables with Tri Hita Karana variables on burnout is not significant, so the moderating relationship between Tri Hita Karana's culture and role ambiguity in burnout is not a moderator, but is intervening, exogenous, antecedent or predictor (independent).

The hypothesis (H3) states that the Tri Hita Karana Culture weakens the influence of the role overload on burnout. Table 5.7 above shows that the Tri Hita Karana Culture weakens the influence of the role overload on burnout is significant with a p-value of 0.031 , less than 0.05 . The original sample estimate value is negative which is equal to 0.231 which indicates that the Tri Hita Karanam culture weakens the influence of the role overload on burnout. Thus the H3 hypothesis in this study which states that the culture of Tri Hita Karanam weakens the influence of role overload on burnout is accepted.

The relationship of the Tri Hita Karan cultural variable with the dependent variable can be seen from the significance value with a p-value of 0,000 , less than 0.05 . The interaction of the cultural variable Tri Hita Karana with the independent variable can be seen from the significance value of the interaction of the role overload variable with the cultural variable Tri Hita Karana which is p-value of 0.031, smaller than 0.05 . This shows that the interaction of the role overload variable with the Tri Hita Karana variable on burnout is significant, so the moderating relationship between Tri Hita Karana culture and the role overload $\mathrm{n}$ burnout is the quasi moderator.

\section{Conclusion}

The results showed that the culture of Tri Hita Karana weakened the influence of role conflict and the role of overload in burnout. Tri Hita Karana's culture and the role overload faced by APIP, thus reducing the occurrence of burnout. For this reason, it is recommended to consider the cultural aspects of Tri Hita Karana in the organizational culture at the Inspectorate of Bali Province in order to improve harmony and harmony in APIP behavior, so as to help overcome role conflicts and the excess roles they face in carrying out their duties.

The results of this study indicate that the moderating relationship between Tri Hita Karana culture and the role ambiguity on APIP burnout are not moderators, but are intervening, exogenous, antecedent, or predictors. For further research, it is recommended to consider other variables that are able to moderate the influence of role conflict, role ambiguity, and the role overload in APIP burnout, and further research can use different respondents, such as external auditors.

The results showed that the average score on the tolerance indicator obtained the lowest value so that it showed low mutual respect and respect among fellow APIPs, so it was suggested to the Bali Provincial Inspectorate to

Pratiwi, I. Y., Ratnadi, N. M. D., Suprasto, H. B., \& Sujana, I. K. (2019). The effect of role conflict, role ambiguity, and role overload in burnout government internal supervisors with tri hita karana culture as moderation. International Research Journal of Management, IT and Social Sciences, 6(3), 61-69. 
emphasize the implementation of the tolerance values so that harmonious relations between APIPs were maintained in creating conducive working conditions.

\section{Limitation}

Based on the research that has been done, there are limitations, namely the instruments in this study only use questionnaires. Data collection is only done by distributing questionnaires. Further research should conduct interviews with respondents related to the cultural understanding of Tri Hita Karana or provide open questions on special questionnaires concerning perceptions and understandings related to the culture of Tri Hita Karana.

Conflict of interest statement and funding sources

The authors declared that they have no competing interest. The study was financed by personal funding.

Statement of authorship

The authors have a responsibility for the conception and design of the study. The authors have approved the final article.

\section{Acknowledgments}

The authors would like to acknowledge the editor of IRJMIS for their support, valuable time, and advice in completing the present article. 


\section{References}

Adiputra, I. N., Sugihartini, N., \& Wahyuni, D. S. (2014). Pengembangan E-Modul pada Materi "Melakukan Instalasi Sistem Operasi Jaringan Berbasis GUI dan Text" untuk Siswa Kelas X Teknik Komputer dan Jaringan SMK Negeri 3 Singaraja. Singaraja: Universitas Pendidikan Ganesha.

Ariyanto, K. (2014). Analyzing the Conflict between Football Organizations in Indonesia. Procedia-Social and Behavioral Sciences, 115, 430-435.

Bakar, N. H., Kasirun, Z. M., \& Salleh, N. (2015). Feature extraction approaches from natural language requirements for reuse in software product lines: A systematic literature review. Journal of Systems and Software, 106, 132-149. https://doi.org/10.1016/j.jss.2015.05.006

Budiadnyani, I. G. A. (2017). Pengaruh Jenis Dan Konsentrasi Adsorben Terhadap Karakteristik Fisikokimia Minyak Ikan Dari Hasil Samping Industri Pengalengan Tuna Madidihang (Thunnus Albacares). Technology Science and Engineering Journal, 1(2).

Budiadnyani, I. G. A. (2017). Pengaruh Jenis Dan Konsentrasi Adsorben Terhadap Karakteristik Fisikokimia Minyak Ikan Dari Hasil Samping Industri Pengalengan Tuna Madidihang (Thunnus Albacares). Technology Science and Engineering Journal, 1(2).

Cordes, C. L., \& Dougherty, T. W. (1993). A review and an integration of research on job burnout. Academy of management review, 18(4), 621-656. https://doi.org/10.5465/amr.1993.9402210153

Dewi, I. G. A. A. O., Dewi, I. G. A. A. P., Kustina, K. T., \& Prena, G. D. (2018). Culture of tri hita karana on ease of use perception and use of accounting information system. International Journal of Social Sciences and Humanities, 2(2), 77-86. https://doi.org/10.29332/ijssh.v2n2.131

Fogarty, T. J., Singh, J., Rhoads, G. K., \& Moore, R. K. (2000). Antecedents and consequences of burnout in accounting: Beyond the role stress model. Behavioral Research in Accounting, 12, 31-68.

Freudenberger, H. J. (1974). Staff burn-out. Journal of social issues, 30(1), 159-165. https://doi.org/10.1111/j.15404560.1974.tb00706.x

Ghorpade, J., Lackritz, J., \& Singh, G. (2011). Personality as a moderator of the relationship between role conflict, role ambiguity, and burnout. Journal of Applied Social Psychology, 41(6), 1275-1298. https://doi.org/10.1111/j.1559-1816.2011.00763.x

Ghozali, I. (2013). Aplikasi Analisis Multivariate Dengan Program. Edisi Ketujuh. Semarang: Badan Penerbit Universitas Diponegoro.

Glazer, S., \& Beehr, T. A. (2005). Consistency of implications of three role stressors across four countries. Journal of Organizational Behavior: The International Journal of Industrial, Occupational and Organizational Psychology and Behavior, 26(5), 467-487. https://doi.org/10.1002/job.326

Gunawan, K. (2009). Pengaruh Budaya Organisasi, Kepuasan Kerja dan Motivasi Kerja terhadap Gaya Kepemimpinan dan Kinerja Organisasi (Studi pada Lembaga Perkreditan Desa (LPD) di Bali). Jurnal Aplikasi Manajemen, 7(2), 441-449.

Idris, M. K. (2011). Over time effects of role stress on psychological strain among Malaysian public university academics. International Journal of Business and Social Science, 2(9), 154-161. https://doi.org/10.1108/14637151211225225

Jawahar, I. M., Stone, T. H., \& Kisamore, J. L. (2007). Role conflict and burnout: The direct and moderating effects of political skill and perceived organizational support on burnout dimensions. International Journal of Stress Management, 14(2), 142. https://doi.org/10.1037/1072-5245.14.2.142

Jones III, A., Norman, C. S., \& Wier, B. (2010). Healthy lifestyle as a coping mechanism for role stress in public accounting. Behavioral Research in Accounting, 22(1), 21-41. https://doi.org/10.2308/bria.2010.22.1.21

Kalbers, L. P., \& Fogarty, T. J. (2005). Antecedents to internal auditor burnout. Journal of Managerial Issues, 101118.

Kusuma, B. H. (2018). Pengaruh Role Stressor Terhadap Burnout dan Perbedaan Burnout Berdasarkan Gender: Studi Empiris pada Mahasiswa. Jurnal Akuntansi Maranatha, 10(1). https://doi.org/10.28932/jam.v10i1.929

Latra, I. W., Ag, S., Si, M., \& Latra, I. W. (2009). Pendidikan agama hindu di perguruan tinggi.

Maslach, C., \& Jackson, S. E. (1981). The measurement of experienced burnout. Journal of organizational behavior, 2(2), 99-113. https://doi.org/10.1002/job.4030020205

Maslach, C., \& Jackson, S. E. (1984). Burnout in organizational settings. Applied social psychology annual. https://doi.org/10.1093/sw/40.5.638

Pratiwi, I. Y., Ratnadi, N. M. D., Suprasto, H. B., \& Sujana, I. K. (2019). The effect of role conflict, role ambiguity, and role overload in burnout government internal supervisors with tri hita karana culture as moderation. International Research Journal of Management, IT and Social Sciences, 6(3), 61-69. 
Maslach, C., \& Leiter, M. P. (2008). The truth about burnout: How organizations cause personal stress and what to do about it. John Wiley \& Sons.

Maslach, C., Schaufeli, W. B., \& Leiter, M. P. (2001). Job burnout. Annual review of psychology, 52(1), $397-422$.

Murtiasri, E. (2007). Anteseden dan Konsekuensi Burnout pada Auditor: Pengembangan terhadap Role Stress Model. MAKSI, 7.

Musktikayani, N. L. P. D., \& Dwirandra, A. A. N. B. Budaya tri hita karana sebagai pemoderasi kompleksitas tugas dan tekanan waktu terhadap kinerja auditor. E-Jurnal Akuntansi, 1544-1573.

Pitana, I. G. (2002). Apresiasi kritis terhadap kepariwisataan Bali. The Works.

Putra, I. G. M. (2000). THK dalam Arsitektur Bali, dalam kumpulan makalah Konsep dan Implementasi THK dalam Pembangunan Bali Menyongsong Pelaksanaan Otonomi Daerah. Pusat Kajian Bali.

Riana, I. G., Zain, D., Troena, E. A., \& Sudarma, M. (2011). Dampak Penerapan Budaya Tri Hita Karana terhadap Orientasi Kewirausahaan dan Orientasi Pasar serta Konsekuensinya pada Kinerja Usaha (Studi pada Industri Kecil Menengah Kerajinan Perak di Bali). Jurnal Aplikasi Manajemen, 9(2), 601-610.

Robbins, M., Judge, A., Ambegia, E., Choi, C., Yaworski, E., Palmer, L., ... \& MacLachlan, I. (2008). Misinterpreting the therapeutic effects of small interfering RNA caused by immune stimulation. Human gene therapy, 19(10), 991999. https://doi.org/10.1089/hum.2008.131

Selye, H. (1975). Confusion and controversy in the stress field. Journal of human stress, 1(2), 37-44. https://doi.org/10.1080/0097840X.1975.9940406

Stein, G., \& Van Vechten, C. (1990). Selected Writings of Gertrude Stein. Vintage.

Utami, I., \& Nahartyo, E. (2013). Auditors'personality in increasing the burnout. Journal of Economics, Business \& Accountancy Ventura, 16(1). http://dx.doi.org/10.14414/jebav.v16i1.132

Viator, R. E. (2001). The association of formal and informal public accounting mentoring with role stress and related job outcomes. Accounting, Organizations and Society, 26(1), 73-93. https://doi.org/10.1016/S03613682(00)00002-7

Wiana, I. K. (2007). Tri Hita Karana Menurut Konsep Hindu. Surabaya: Paramita.

Wikaningtyas, T. S. (2007). Hubungan Antara Perilaku Tipe A dan Tipe B dengan Stres Kerja. E-Jurnal Fakultas Psikologi, Universitas Indonesia.

Windia, W., \& Dewi, R. K. (2007). Analisis Bisnis yang Berlandaskan Tri Hita Karana. Universitas Udayana.

Wirakusuma, M. G., Rasmini, N. K., \& Wiryathi, N. M. (2014). Pengaruh Role Stressors pada Burnout Auditor dengan Kecerdasan Emosional sebagai Variabel Pemoderasi (Studi Empiris pada Kantor Akuntan Publik Se-provinsi Bali). E-Jurnal Ekonomi dan Bisnis Universitas Udayana.

Yustrianthe, R. H. (2008). Pengaruh flexible work arrangement terhadap role conflict, role overload, reduced personal accomplishment, job satisfaction dan intention to stay. Jurnal bisnis dan akuntansi, 10(3), 127-138. 


\section{Biography of Author}

\begin{tabular}{|l|l|}
\hline Ida Yuni Pratiwi was born in Denpasar. Currently as a young entrepreneur that interesting \\
in the accounting field. She finished her studies at Udayana University Master of \\
Accounting. \\
Email: idayupy8@gmail.com
\end{tabular}

Pratiwi, I. Y., Ratnadi, N. M. D., Suprasto, H. B., \& Sujana, I. K. (2019). The effect of role conflict, role ambiguity, and role overload in burnout government internal supervisors with tri hita karana culture as moderation. International Research Journal of Management, IT and Social Sciences, 6(3), 61-69. https://doi.org/10.21744/irjmis.v6n3.630 